\title{
European Parliamentary Oversight Behind Closed Doors
}

\author{
Vigjilenca Abazi*
}

\begin{abstract}
The lack of transparency in European Union (EU) decision-making and integration has been a long-standing concern in academic and public debate. Perhaps paradoxically, parliamentary oversight of executive power in the EU is also increasingly taking place behind closed doors. This closed oversight results from internal rule-making and interinstitutional agreements established by the European Parliament and executive actors without a public debate and is primarily aimed at safeguarding EU official secrets. This paper examines the role of the European Parliament in oversight in the context of EU executive secrecy. The paper argues that, although the European Parliament asserts its prerogatives for gaining access to EU official secrets, its current practice of closed oversight does not facilitate public deliberation. The European Parliament is yet to make serious efforts to develop its public deliberation function and, in doing so, to also bring attention to possible extensive secrecy practices.
\end{abstract}

\section{Keywords}

European Parliament, oversight, access to information, secrecy, deliberation, executive power

\section{Introduction}

The lack of transparency in European Union (EU) decision-making and integration has been a long-standing concern in academic and public debate. ${ }^{1}$ EU integration is

* Assistant Professor at University of Maastricht and Research Coordinator at the Centre for European Research in Maastricht (CERiM). An earlier draft of this paper was presented at the Durham-Cambridge Doctoral Workshop in EU Law 'Igniting European Union Law: Frameworks for the Future' at Durham University, 5-6 March 2015. The author would like to thank the organisers for their invitation and the commentators Dr. Markus Gehring and Dr. Andrés Delgado Casteleiro for their valuable comments. Usual disclaimer applies.

1 See Deirdre Curtin and Maarten Hillebrandt, 'Transparency in the EU: Constitutional overtones, institutional dynamics, and the escape hatch of secrecy', in Steven Blockmans and Adam Lazowski (eds), Research Handbook on EU Institutional Law (Edward Elgar 2016) (forthcoming). 
described as having developed through stealth and competence creep. ${ }^{2}$ Furthermore, the growing executive power of the EU is exercised in a 'shadowy' manner by an ever-expanding array of institutions, agencies and other actors. ${ }^{3}$ Meetings of EU executive actors behind closed doors are still commonplace for crucial policy issues, such as the euro crisis, or the negotiations of international agreements with tremendous impact, such as the Transatlantic Trade and Investment Partnership with the United States. ${ }^{4}$

Perhaps paradoxically, parliamentary oversight of executive power in the EU is also increasingly taking place behind closed doors. This closed oversight results from internal rule-making and interinstitutional agreements established by the European Parliament and executive actors primarily aimed at safeguarding EU official secrets. The latter, more technically known as European Union Classified Information (EUCI), set rigid and very specific rules as to what may be a secret, who determines this, who can see it and who cannot. ${ }^{5}$ Consequently, when access to a sensitive document labelled as ' $E U$ Confidential' is granted to the European Parliament, only selected Members of the European Parliament (MEPs) may read this document. ${ }^{6}$ These 'privileged' MEPs cannot take any notes or have their phone devices with them in the strictly protected and secured facilities designated specifically for reading the relevant classified document. ${ }^{7}$ They can neither mention it to the news media nor discuss any content related to the document publically. ${ }^{8}$

2 See Giandomenico Majone, Dilemmas of European Integration: The Ambiguities and Pitfalls of Integration by Stealth (OUP 2005); Ramses A Wessel, 'Integration by Stealth: On the Exclusivity of Community Competence' in Daniela Obradovic and Nikos Lavranos (eds), Interface between EU Law and National Law (Europa Law Publishing 2007) 43-50; Mark Pollack, 'Creeping Competence: The Expanding Agenda of the European Community' (1994) $14 \mathrm{~J}$ Pub Pol'y 95.

3 See Deidre Curtin, Executive Power of the European Union: Law, Practices, and the Living Constitution (OUP 2009) 51-52.

4 See Vigjilenca Abazi and Maarten Hillebrandt, 'The Legal Limits to Confidential Negotiations: Recent Case Law Developments in Council Transparency: Access Info Europe and in 't Veld' (2015) 52 CML Rev 825.

5 See, eg, the EUCI rules of the Council, Council Decision 2013/488/EU of 23 September 2013 on the security rules for protecting EU classified information [2013] OJ L274/1.

6 See Interinstitutional Agreement of 12 March 2014 between the European Parliament and the Council concerning the forwarding to and handling by the European Parliament of classified information held by the Council on matters other than those in the area of the common foreign and security policy [2014] OJ C95/1 art 5.

$7 \quad$ ibid art 6.

8 ibid. 
As an interviewed former MEP acknowledged, these rigid rules in support of confidentiality make oversight 'difficult or impossible."

Another important aspect of closed oversight, thus far neglected in the literature, is that it challenges the essential role of the European Parliament to promote public deliberation. Public deliberation is highly salient from a democratic perspective in order to include citizens' contributions to EU decision-making. The European Parliament is the only directly elected EU institution and the main public deliberation platform making openness and debate crucial to its workings.

This paper examines the oversight role of the European Parliament in the context of EU executive secrecy. It reveals that the European Parliament asserts its oversight role, but that current practice does not meet the standard of democratic oversight facilitating public deliberation. European parliamentary oversight could contribute to public deliberation as an equally salient democratic process if it were conducted in a more open manner, or if the oversight results were reported and/or discussed publically.

The paper proceeds as follows: Section II provides the key aspects of the legal framework of EU official secrets, focusing on the main challenge of accessing information. It discusses the efforts of the European Parliament to countervail these limitations as well as the outcome of these efforts. Section III examines in more detail how oversight by the European Parliament takes place and thereupon critically assesses its implications particularly for public deliberation. Section IV offers some conclusions.

\section{EU secrecy: an invincible parliamentary challenge?}

'Monetary policy is a serious issue. We should discuss this in secret. I am ready to be insulted as being insufficiently democratic, but I want to be serious (...) I am for dark, secret debates. ${ }^{10}$

This is a frank response by the current President of the European Commission to the questions of journalists regarding the coordination of the euro crisis. Although (February 2015)); see also Andrew Rettman, 'Secret documents group was like "bad Le Carre novel," MEP says' EU Observer (Brussels, 18 November 2010).

10 Valentina Pop, 'Eurogroup Chief: "I'm for secret, dark debates"' EU Observer (Brussels, 21 April 2011). 
anecdotal, this statement nonetheless illustrates a longstanding preference for secrecy in the European Union. ${ }^{11}$ Secrecy may be understood as the inaccessibility of information about an actor, which prevents other actors from monitoring the workings or performance of this actor. ${ }^{12}$ Secrecy in the EU is manifest, not only in the form of closed door meetings, but predominately also in a growing set of rules regarding the creation and management of official secrets, the EUCI. These rules establish extremely rigid limitations of access to sensitive information and have become a real challenge to conducting oversight in the EU, be it of a judicial, administrative or parliamentary nature. ${ }^{13}$ This section outlines the main aspects of the EUCI legal framework and focuses on the extent to which MEPs have access to official secrets. Moreover, the section examines the institutional efforts of the European Parliament to address the challenges that arise due to limited or belated access to official secrets.

\subsection{Parliamentary access to EU official secrets}

Challenges to parliamentary oversight in the EU arise due to the fact that the EUCI significantly limits access to relevant sensitive information. The EUCI legal framework is fragmented and of an administrative nature. Different rules on access to official secrets apply in the Member States that in turn affect access to official secrets at the EU level. Yet, the framework of rules on official secrets is also varied at the EU level and a variety of actors are involved, such as executive institutions like the Council and the Commission, but also bodies like the European External

11 Patrick Birkinshaw, Freedom of Information: The Law, the Practice and the Ideal (4th edn, CUP 2010) 381-97.

12 See, by contrast, the definition of transparency in Albert Meijer, 'Understanding the Complex Dynamics of Transparency' (2013) 73 Pub Adm Rev 429, 430.

13 See Deidre Curtin, 'Overseeing Secrets in the EU: A Democratic Perspective' (2014) 52 J Common Market Studies 684; Christina Eckes, 'Decision-making in the Dark? Autonomous EU Sanctions and National Classification' in Iain Cameron (ed), EU Sanctions: Law and Policy Issues Concerning Restrictive Measures (Intersentia 2013) 177-97; Nik de Boer, 'Secret Evidence and Due Process Rights under EU Law: ZZ' (2014) 51 CML Rev 1235; European Ombudsman Emily O’Reilly, 'Decision of the European Ombudsman closing the inquiry into complaint 1148/2013/TN as regards Europol' (European Ombudsman, 8 January 2015) <http://www.ombudsman.europa.eu/activities/speech.faces/en/58671/html.bookmark> accessed 10 February 2016. 
Action Service or agencies such as Europol. ${ }^{14}$ The only directly relevant legislative act for the system of classified information is Regulation 1049/01-the Transparency Regulation, regarding the right to public access of information in the EU. ${ }^{15}$ Therein, Article 9 defines the category of classified information as 'sensitive documents (...) which protect essential interests of the European Union or of one or more of its Member States in the areas (...) [of] public security, defence and military matters. Regulation 1049/01 does not specify the general principles regarding the management of EUCI, nor is it its legal rationale to do so. ${ }^{16}$ It merely points to a different handling process for public access requests of EUCI due to their sensitive nature.

The internal administrative nature of the EUCI system already reflects the fact that the European Parliament did not have a direct say in the manner in which classification rules were to be established. Moreover, to a great extent, the executive actors ignored the calls of the European Parliament for openness, considering that the EUCI was treated as an internal administrative policy and there was no legal obligation to consult the European Parliament or request its consent. ${ }^{17}$ The EUCI rules are engineered by executive actors following a security rationale that, in practice, leads to tensions with the European Parliament's oversight prerogatives, specifically with regard to access to official secrets. ${ }^{18}$

The current EUCI system operates on a rigid principle regarding the sharing of information, known as 'originator control', which gives the original institution that created the official secret the discretion to decide whether its disclosure may be

14 The following decisions are applicable: Council Decision 2013/488/EU of 23 November 2013 on the security rules for protecting EU classified information [2013] OJ L 274; Council Decision 2009/968/JHA of 30 November 2009 adopting the rules on the confidentiality of Europol information OJ 2009 [2009] L 332/17; Decision of the High Representative of the Union for Foreign Affairs and Security Policy 2013/C 190/01 of 19 April 2013 on the security rules for the European External Action Service [2013] OJ C 190/1; European Commission Rules of Procedure (C(2000) 3614) of 8.12.2000 [2000] OJ L 308, amended by European Commission Decision 2011/737/EU, Euratom of 9 November 2011 [2011] OJ L 296.

15 European Parliament and Council Regulation 1049/2001 of 30 May 2001 regarding Public Access to European Parliament, Council and Commission documents [2001] OJ L145/43.

16 See Vigjilenca Abazi and Eljalill Tauschinsky, 'Reasons of Control and Trust: Grounding the Public Need for Transparency in the European Union' (2015) 11 Utrecht LR 78.

17 See David Galloway, 'Classifying Secrets in the EU' (2014) 52 J Common Market Studies 668; for a different view see Curtin (n 13).

18 Deidre Curtin, 'Top Secret Europe', Inaugural lecture delivered at the University of Amsterdam (20 October 2011) <http://www.oratiereeks.nl/upload/pdf/PDF-5066weboratie_Curtin.pdf> accessed 1 April 2016. 
authorised. ${ }^{19}$ In other words, originator control means that the actor who provides the classified information retains complete control over its dissemination by other actors with whom such information has initially been shared. This rule aims at safeguarding the originators' discretion. This key principle of the classification system leads to an inevitable clash between, on the one hand, confidentiality and trust amongst executive actors that maintain the secrets and, on the other hand, the accessibility of information for oversight institutions, such as the European Parliament. In this respect, recent contributions have recognised that access to official secrets is the main challenge for the European Parliament, be it with regard to oversight in law enforcement cooperation, ${ }^{20}$ the Common Security and Defence Policy, ${ }^{21}$ or international negotiations. ${ }^{22}$

A recent example in this regard is the limitation of access of the European Parliament to a report concerning the EU-US Terrorist Finance Tracking Program Agreement (TFTP). ${ }^{23}$ The TFTP provides for the EU to transmit financial messaging data to the United States Treasury Department, while Article 4 of the Agreement assigns Europol, an EU intelligence agency, the task of verifying whether requests from the US authorities to obtain such data from the EU comply with the specified criteria. ${ }^{24}$ A Member of the European Parliament filed for access to the document on the implementation of the agreement. The access request was denied by Europol, however, because the US Treasury Departmentbeing the originator of the classified document-refused to allow access to the report. ${ }^{25}$ It is indeed quite remarkable that the US Treasury Department, due to arrangements between executives regarding how secrets may be shared, is able

See Council Decision 2013/488/EU of 23 September 2013 on the security rules for protecting EU classified information [2013] OJ L274/1 arts 2 and 13.

20 See Vigjilenca Abazi, 'The Future of Europol's Parliamentary Oversight: A Great Leap Forward?' (2014) 15 German LJ 1121.

21 Guri Rosén, 'EU Confidential: The European Parliament's Involvement in EU Security and Defence Policy' (2015) 53 J Common Market Studies 383.

22 Deidre Curtin, 'Official Secrets and the Negotiation of International Agreements: Is the EU Executive Unbound?' (2013) 50 CML Rev 423.

23 Agreement between the European Union and the United States of America on the Processing and Transfer of Financial Messaging Data from the European Union to the United States for the Purposes of the Terrorist Finance Tracking Program [2010] OJ L195/5.

24 Elaine Fahey, 'Law and Governance as Checks and Balances in Transatlantic Security: Rights, Redress and Remedies in EU-US Passenger Name Records and the Terrorist Finance Tracking Program' (2013) 32 YB Eur L 368.

25 Nikolaj Nielsen, 'US gag order on EU police agency stirs controversy' EU Observer (Brussels, 8 January 2015). 
to block parliamentary oversight. Moreover, these arrangements were made on a bilateral basis by the agency and never approved by the European Parliament. ${ }^{26}$ In the EU practice of oversight, there are also other examples of limitations of access to official secrets applied by the Council and the Commission. For instance, the Committee on Civil Liberties, Justice and Home Affairs has noted the lack of access to classified information regarding the Schengen Information System for Bulgaria and Romania. ${ }^{27}$ In this case, the European Parliament received important classified information through diplomatic channels of exchange with the Romanian Ambassador, instead of being granted access to classified information directly from the Council. ${ }^{28}$ Limitations on the sharing of information have also been noted within the relations of the European Parliament and the Commission. ${ }^{29}$ In light of these significant limitations of access to official secrets, the question arises as to how the European Parliament can counterbalance executive secrecy. The following subsection examines this aspect of parliamentary oversight.

\subsection{Institutional responses to challenges of secrecy}

The European Parliament has made significant efforts to address the limitations of access to information imposed by EU official secrets rules. One of the first steps of the European Parliament to be able to access classified information was to establish an internal system on EUCI. ${ }^{30}$

The European Parliament's legal framework and practice with regards to classified information is recent. The first reference to 'confidentiality' concerning the European Parliament is found in its 1989 Rules of Procedure. Annex VII of

26 See also European Parliament Legal Service, Legal Opinion Regarding the European Ombudsman's Access to Documents Concerning Europol's Activities Under the TFTP Agreement (Document SJ- 1058/14, D(2015)1986, 2 February 2015) <http://www.europarl.europa.eu/ RegData/publications/avis/2015/0001/EP-PE_AVS(2015)0001_XL.pdf> accessed 10 February 2015.

27 General Secretariat of the Council, Summary of the Meeting of the European Parliament Committee on Civil Liberties, Justice and Home Affairs (LIBE) (Brussels, 31 May and 1 June 2010), Document No 10699/10 (4 June 2010). ibid.

29 Sergio Carrera, Nicholas Hernanz and Joanna Parkin, 'The "Lisbonisation" of the European Parliament: Assessing Progress, Shortcomings and Challenges for Democratic Accountability in the Area of Freedom, Security and Justice' (2013) CEPS Working Paper No $58<$ http://aei. pitt.edu/44126/1/LSE_No_58_Lisbonisation_of_EP.pdf > accessed 10 February 2016. Galloway (n 17). 
the 1989 Rules of Procedure stipulated general rules with regard to confidentiality, which were amended in 2001 on the basis of the Maij-Weggen report ${ }^{31}$ due to the adoption of Regulation 1049/01 on public access to documents. At this stage, the European Parliament did not have other specific rules on classified information, nor did it have agreements for the exchange of classified information. With the enactment of Regulation 1049/01, the European Parliament made further changes to its Rules of Procedure, especially regarding the notion of confidentiality as a reason to restrict information and access to documents. The European Parliament aligned its system with Article 4 and Article 9 of Regulation 1049/01 as the only basis for the possible rejection of public access to documents. According to the new changes, confidential documents were only excluded from public access by virtue of Article 4 of Regulation (EC) 1049/2001 and the European Parliament's confidentiality rules in Annex VII could not, as such, be the basis for the nondisclosure of documents. The European Parliament's revision of its rules on confidentiality was triggered by the necessity to exchange classified information with the executive actors. The first step towards the exchange of classified information between the Council and the European Parliament was the Agreement in 2002 regarding classified information in the area of security and foreign policy. ${ }^{32}$

The European Parliament's internal rules on classified information are also of an administrative nature. The Bureau of the European Parliament, which is composed of the President and the 14 Vice-Presidents of the European Parliament, established the internal organisation for European Parliament classified information. ${ }^{33}$ The Bureau established the internal rules on EUCI taking into account the interinstitutional agreements that the European Parliament had with the Council and the Commission for exchange of classified documents. ${ }^{34}$ Prior to the Bureau's Decision, which specifically addressed the internal organisation with Rules of Procedure to the Regulation (EC) No.1049/2001 of the European Parliament and of the Council regarding Public Access to Documents (2001/2135(REG)) (15 October 2001).

32 See Interinstitutional Agreement of 20 November 2002 between the European Parliament and the Council concerning access by the European Parliament to sensitive information of the Council in the field of security and defence policy [2002] OJ C298/1.

33 See European Parliament Rules of Procedure of September 2015, rule $22<\mathrm{http}: / /$ www.europarl.europa.eu/sides/getDoc.do?pubRef=-//EP//NONSGML+RULES$\mathrm{EP}+20150909+0+\mathrm{DOC}+\mathrm{PDF}+\mathrm{V} 0 / / \mathrm{EN} \&$ language=EN $>$ accessed 10 February 2016. ibid rule 23 . 
regard to classified information, the European Parliament's Decision of 23 October $2002^{35}$ - which provided a basis for the implementation of the Interinstitutional Agreement with the Council-had set out the basic principles and the necessary measures for being able to exchange information in the area of security and foreign policy. It is noteworthy that the manner in which the Bureau established the rules of classification is similar to the executive institutions. This implies that the Bureau did not carry out any public deliberation about the rules. Furthermore, the fact that only the Bureau has worked on the rules since their establishment shows that this was also considered an administrative and internal institutional matter. ${ }^{36}$

The institutional negotiations for the European Parliament to be granted access have been long and arduous. ${ }^{37}$ The implication from the fragmented nature of the classification system is that the European Parliament negotiated separately with each institution regarding access to EUCI and with some actors, like Europol, it is only now, through its newly gained oversight prerogatives, that access would be legally possible. ${ }^{38}$ Furthermore, in the post-Lisbon context, the European Parliament and the Council still have 'diverging perceptions' on access to classified information, and this issue of access was a matter of discussion in several meetings of the Conference of Presidents of the European Parliament. ${ }^{39}$ The European Parliament has stressed that it is of 'utmost importance' to begin negotiations with the Council with a view to amending the 2002 Interinstitutional

Decision of the European Parliament of 23 October 2002 on the Implementation of the Interinstitutional Agreement Governing European Parliament Access to Sensitive Council Information in the Sphere of Security and Defence Policy [2002] OJ C 298/4-5. European Parliament Rules of Procedure (n 33) art 25(12): 'The Bureau shall lay down rules concerning the treatment of confidential information by Parliament and its bodies, officeholders and other Members, taking into account any interinstitutional agreement concluded on such matters. Those rules shall be published in the Official Journal of the European Union and annexed to these Rules of Procedure. European Parliament Resolution 2010/2294(INI) of 14 September 2011 on public access to documents (Rule 104(7)) for the years 2009-2010 [2013] C 51 E/72 Point N.

38 Abazi (n 20).

39 On 15 March 2012 the Conference of Presidents endorsed the outcome of negotiations on a draft interinstitutional agreement concerning the forwarding to, and handling by, the European Parliament of classified information held by Council on matters other than those in the area of the Common Foreign and Security Policy and referred the draft IIA to the Committee on Constitutional Affairs pursuant to rule 127 of the Rules of Procedure. The negotiations resulted in the beginning of March 2012 in a jointly agreed draft text for an interinstitutional agreement on access to classified information held by the Council. 
Agreement to reflect both the reforms carried out since it was concluded and the current situation of increased prerogatives. ${ }^{40}$

The broader oversight powers of the European Parliament in the context of post-Lisbon reforms of new parliamentary checks are of significant value in enabling the European Parliament to address the limitations of access to official secrets. In this regard, the new explicit prerogative set in primary law for the European Parliament to be informed of international agreements, ${ }^{41}$ as well as the initiation of adjudication as a means to receive information from the EU executive institutions have become salient means for the European Parliament to be informed. A recent example is the case, C-658/11 Parliament $v$ Council, ${ }^{42}$ in which the Court reiterated the relevance and applicability of the European Parliament's access to the relevant information stipulated in Article 218(10) of the Treaty for the Functioning of the European Union (TFEU). Although the issue in this case is not strictly related to access to classified information, the case is significant for the information-sharing obligations required of the executive actors in light of the Court's interpretation of the principle of sincere cooperation. The Court interpreted the principle of sincere cooperation and information-sharing obligations between the institutions rather broadly to include even issues strictly pertaining to the Common Foreign and Security Policy, ${ }^{43}$ an area of EU policy where the European Parliament has no political oversight powers. ${ }^{44}$

Besides judicial avenues as a means to attain access to information, the European Parliament uses its veto powers gained as a result of the Lisbon Treaty reforms. For example, in line with Article 218(6)(a) TFEU, the European Parliament has the power to provide or refuse its consent to the final text of an international agreement negotiated by the Commission. In this respect, recent research shows interinstitutional agreement between the European Parliament and the Council concerning the forwarding to, and handling by, the European Parliament of classified information held by the Council on matters other than those in the area of the common foreign and security policy 2012/2069, A7-0245/2012 (ACI) of 18 July 2012, point 4 <http://www.europarl.europa.eu/ sides/getDoc.do?pubRef=-//EP//NONSGML+REPORT+A7-2012-0245+0+DOC+PDF+V0// EN> accessed 10 February 2016.

41 Consolidated Version of the Treaty on the Functioning of the European Union [2012] OJ 326/47 (TFEU) art 218(10).

42 Case C-658/11 European Parliament v Council of the European Union [2014] OJ C292/2.

43 ibid para 85.

44 TFEU (n 41) art 218(6). 
that the European Parliament uses the veto on the external issues of EU law to also strengthen its position internally, ${ }^{45}$ and it does so by refusing or delaying consent. ${ }^{46}$ For example, the European Parliament refused consent to the EU-US Society for Worldwide Interbank Financial Telecommunication (SWIFT) Agreement and delayed consent to the USA and Australia Passenger Name Records Agreements. Regarding the SWIFT Agreement, the European Parliament gave its consent at a later stage but, as some scholars note, there were 'no remarkable differences between the first and second SWIFT agreements. ${ }^{, 47}$ Rather, the difference was that, on the second round, the European Parliament was fully informed at all stages of the negotiations. ${ }^{48}$

The European Parliament also has new legislative powers in the Area of Freedom, Security and Justice and has used such powers to enhance its access to classified information. For example, in line with Article 88 TFEU, the European Parliament has become a co-legislator in issues relating to law enforcement cooperation, and on this basis, the European Parliament is in the process of setting up a regime for access to classified information held by Europol. Moreover, even when the European Parliament does not have legislative powers, and is not directly involved in setting up EU bodies, it has used its prerogatives over the EU budget in order to assert its oversight position. ${ }^{49}$ For example, in the establishment of the European External Action Service (EEAS), the initial proposals did not contain an explicit right for the European Parliament to have access to the EEAS's classified information. However, the European Parliament on its first position regarding the establishment of the EEAS, was explicit in its ambition to gain access to classified information by calling for a modification of the draft text. Without adopting a separate legal arrangement with the EEAS for access to its classified information,

45 See Christina Eckes, 'How the European Parliament's Participation in International Relations Affects the Deep Tissue of the EU's Power Structures' (2014) 12 Int'l J Const L 904.

46 See Jörg Monar, 'The Rejection of the EU-US SWIFT Agreement by the European Parliament: A Historic Vote and Its Implications' (2010) 15 Eur Foreign Aff Rev 143.

47 See Juan Santos Vara, 'The Role of the European Parliament in the Conclusion of the Transatlantic Agreements on the Transfer of Personal Data after Lisbon', CLEER Working Papers 2013/2 <http://www.asser.nl/upload/documents/20130226T013310-cleer_13-2_web. pdf $>$ accessed 10 February 2016.

48 ibid 20.

49 Leendert Erkelens and Steven Blockmans, 'Setting Up the European External Action Service: An Institutional Act of Balance, CLEER Working Papers 2012/1, $20<$ http://www.asser.nl/ media/1630/cleer2012-1web.pdf> accessed 1 April 2016. 
the European Parliament wanted to apply the existing provisions of the 2002 Interinstitutional Agreement on classified information in the area of security and defence policy concluded with the Council. ${ }^{50}$ These efforts of the European Parliament for access to EEAS classified information were successful, taking into account that the final Council Decision stipulates in the preamble (paragraph 6) that the European Parliament has access to classified information in accordance with the 2002 Interinstitutional Agreement.

Lastly, access to relevant information may also be facilitated through cooperation between the European Parliament and national parliaments. For example, empirical research shows that, when inter-parliamentary meetings take place between the European Parliament and the national parliaments, they mostly discuss and refer to issues related to oversight within questions of security and foreign policy. ${ }^{51}$

In light of the discussion thus far regarding access to classified information and the European Parliament's efforts to overcome the limits imposed by executive actors, it becomes apparent that the European Parliament has indeed moved forward institutionally to assert its oversight role. Although in practice, limitations of access to classified information in a timely manner is not a foregone issue, in the current legal context, to a significant extent, the European Parliament manages to receive the relevant information for oversight due to its internal rules for EUCI as well as its broader oversight powers, such as consent to international treaties and budgetary powers. Hence, the main aspect in the interplay of parliamentary oversight and executive secrecy is no longer only access to classified information, but also the question of how such access takes place and what are the significant consequences for the democratic role of the European Parliament to have access to classified information.

50 European Communities, Interinstitutional Agreement between the European Parliament and the Council 2002/C 298/01 of 30 November 2002 concerning access by the European Parliament to sensitive information of the Council in the field of security and defence policy [2002] OJ C298/1.

51 European Parliament, Report on Interparliamentary relations between the European Parliament and national Parliaments under the Lisbon Treaty, Annual Report 2013/2014 <http://www.europarl.europa.eu/webnp/webdav/site/myjahiasite/shared/Publications/ Annual report/Relations with National Parliaments - Annual Report 202013.pdf> accessed 3 March 2016. 


\section{Closed parliamentary oversight vs public debate}

The manner in which parliamentary oversight takes place in the EU, insofar as the EUCI is concerned, has been a somewhat neglected element in the discussion regarding the role of the European Parliament and executive secrecy. This section aims to fill that gap by examining how parliamentary oversight takes place. In particular, under what conditions, and using what methods, do the MEPs-and possibly their staff-access classified information? What precisely can they do once they access those documents?

\subsection{Reviewing documents à huis clos}

When requests for access to classified information are approved by executive actors in line with the prerogatives of the European Parliament for oversight, documents are reviewed at the premises of the Council. ${ }^{52}$ Access to EUCI may be granted to the President of the European Parliament and what the Interinstitutional Agreement on classified information calls a 'special committee. The 'special committee' is comprised of only five individuals, namely the Chairman of the Committee of Foreign Affairs and four members designated by the Conference of Presidents. ${ }^{53}$ In addition, there is a difference between individuals who are authorised to make requests for access to classified information and those who actually gain access to EUCI documents and are able to review them. While the former group of individuals is more centralised and focused on the President of the European Parliament, the latter may include the MEPs who have a 'need-to-know', which is

52 This was especially the case before the European Parliament adopted internal EUCI rules for the handling of classified information, as Council officials expressed concerns regarding the security arrangements in place in the premises of the European Parliament to review highly sensitive documents. See Galloway (n 17).

53 See Interinstitutional Agreement between the European Parliament and the Council 2002/C 298/01 (n 32) art 3(3); see also the two separate agreements of the European Parliament with the Council on access: Interinstitutional agreement between the European Parliament and the Council of 12 March 2014 (n 6); Draft Arrangement between the European Parliament, the Council and the External Action Service concerning access by the European Parliament to classified information in the area of the Common Foreign and Security Policy of 23 October 2012, Document 15343/12 <http://www.statewatch.org/news/2012/oct/eu-council-ep-accessclass-info-15343-12.pdf> accessed 10 February 2010. 
a key working principle of categorising and limiting access to official secrets. The 'need-to-know' the content of the classified document is determined on the basis of the specific responsibilities of the individual while conducting his or her work. ${ }^{54}$ Hence, there is a discrepancy between individuals authorised to file requests for access to classified information and those individuals who receive the classified documents. Furthermore, only those individuals who the President of the European Parliament considers to have a relevant need to read the classified document in relation to their work conduct the review of the classified documents. ${ }^{55}$ As a result, it is more appropriate to conclude that access and review of classified documents protected through the EUCI system are concentrated with certain MEPs and relevant Committees as opposed to discussing access and review at a level of the European Parliament as an institution. This leads some MEPs to be very sceptical regarding the prospect of successful oversight, even after having gained access to official secrets:

It is very difficult to really scrutinise [considering the conditions in which oversight involving classified information is organised]. You also cannot really talk to each other, to your MEP colleagues. You are not free to work with the classified documents. And the thing is that I and also many colleagues have our staff reading and writing some of the issues, hence when it is about classified information it becomes difficult or impossible to actually do that. ${ }^{56}$

The MEPs that are granted access to EUCI undergo a strict legal and security procedure in order to review the documents. ${ }^{57}$ Furthermore, in accordance with Article 6(5) of the Interinstitutional Agreement, the meetings between the Council and the European Parliament are held behind closed doors when EUCI documents are discussed. Documents are distributed at the beginning of the meeting and collected again at the end; documents may not be copied by any means, such as photocopying or photographing; no notes may be taken; and the minutes of the meeting cannot make any mention of the discussion of the item containing

54 See Interinstitutional agreement between the European Parliament and the Council of 12 March 2014 (n 6) art 4.

55 ibid.

56 Interview with former Member of the European Parliament (Amsterdam, the Netherlands, February 2015).

57 See Interinstitutional Agreement between the European Parliament and the Council of 12 March 2014 (n 6). 
classified information. ${ }^{58}$ Furthermore, for access to documents classified at a higher level than 'EU Confidential', the Council makes arrangements on an ad hoc basis. The experience with the Agreement shows that those documents are accessed at the Council's premises and under strict security, where all the above-mentioned conditions apply. ${ }^{59}$ These arrangements result in parliamentary oversight taking place behind closed doors, or more simply stated, they result in closed oversight. Closed oversight means that both the manner in which oversight is conducted and the results of oversight are not public to the other members of parliament and to the general public.

Closed oversight from the strict perspective of reviewing executive decisionmaking is not necessarily problematic. Should there be issues of wrongdoing or abuse of power by executive actors, the MEPs would be able to report such conduct and initiate the necessary inquiries as well as legal action in accordance with Article 263(2) TFEU. Nevertheless, closed oversight is problematic from the perspective of the democratic process of public deliberation. The role of MEPs is not merely to ensure that executive actors are not breaching their powers, but it is fundamental that they provide the link between what takes place at the executive decision-making level and the European citizens.

\subsection{Implications of closed oversight: Missing public debate}

Keeping oversight means two main things: First, having the powers and second, mobilising the public. I think that the European Parliament has focused and still does the first thing; it is always trying to secure its powers-it is used to doing thatit knows how to do that. Debate is completely underdeveloped. ${ }^{60}$

This was the frank summary of a former Member of the European Parliament regarding the balance and difficulties in ensuring both processes of oversight and public deliberation. The European Parliament seems to be asserting its powers of oversight through its institutional fights to gain access to classified information, even when this type of access to classified information is done in a

58 ibid arts 5-6.

59 Interview with Member of the European Parliament (Amsterdam, the Netherlands, December 2013).

60 Interview with former Member of the European Parliament (Amsterdam, the Netherlands, February 2015). 
very rigid manner that limits (public) usability of the information learned. The main implication of closed oversight is that the European Parliament is unable to foster public deliberation. The oversight role of the European Parliament is not strictly relevant for accountability, which is defined in principle as one actor giving account to another actor followed by the consequences. Oversight is relevant for democratic processes that aim to ensure the formation of public opinion and the formation of public deliberation necessary towards that end. This understanding of the role of the European Parliament is based on a conceptualisation of oversight to facilitate processes of accountability and deliberation as equally relevant for the European project. It is important to highlight in this respect that EU primary law stipulates various sets of processes that are conducive to public deliberation and specific processes that aim to ensure accountability. The EU has a constitutional commitment to democracy and the principle of openness. ${ }^{61}$

Processes of deliberation aim to grant citizens a participatory role in decisionmaking. Deliberation requires that citizens have relevant information to be able to engage in shaping policies and are hence informed about processes of oversight and the exercise of secrecy. From this perspective, it is required that core choices regarding secrecy are made in an open manner and through public debate. Hence, more clarity should be established between what is considered secret and what is open information that may be publically discussed. ${ }^{62}$ In this regard, it has been rightly noted that in a representative democracy 'worthy of its name one of the truly distinctive qualities of parliaments is their publicness, the fact that they constitute a public forum as opposed to an accountability relationship among peers. ${ }^{63}$ It is necessary from this perspective of public deliberation that the MEPs discuss and communicate how the interests and rights of citizens are affected and what is relevant for them to know. The requirements for the exercise of secrecy, which are directed at ensuring deliberation, are that citizens must know that discussions or some decisions are being kept secret. ${ }^{64}$ The necessity of public information for deliberation creates a higher threshold on the question to what extent secrecy should be limited because, in order to realise processes of deliberation, some information should always be directly available to the citizens. Although that 
information does not need to be specific and detailed, it is very relevant that citizens, in broad terms, know what the policy is about, what interests are at stake and what means are suggested to protect those interests. For example, citizens or the European Parliament would know that Europol is conducting an investigation about cybercrime in the EU, but they would not need to know which individuals are being investigated or more specific information about their location, which could possibly jeopardise the outcome of the investigation. Such an approach to availability of information aims to ensure that security concerns are met and public deliberation can take place.

An additional important element is that the outcomes of the oversight process should be public. From this perspective, the question of oversight is not only about 'policing' the actors if there is a wrongdoing, but it is a question of debates that are also oriented towards future prospects of how things should be done and enabling citizens to formulate and express their agreement. Such oversight outcomes may be a public statement, a report or a debate. However, on the basis of the European Parliament's resolutions and statements regarding EUCI and its emphasis on gaining access, rather than fostering transparency and deliberation, it is noticeable that the institutional focus and efforts were centred on the mere point of gaining access to classified information. The European Parliament's main concern was not to be outside the 'secrecy circle' and left uninformed about important EU developments in the area of security and foreign relations. Less attention or concern was paid to the consequences of access to classified information and the manner in which it was organised for the European Parliament's other functions, such as deliberation, or the manner in which access would be organised. Institutional instruments which would allow the European Parliament to be able to make public a clear demarcation of what remains closed are not foreseen in the current EUCI framework, including the European Parliament's own rules about classified information.

Due to closed oversight and the obligations of the European Parliament not to disclose EUCI in any manner, the specific outcomes of the oversight process are not made public. Classified information and its access by MEPs are not allowed to be included even in the meeting minutes. ${ }^{65}$ The consequences of closed oversight when considered with the fact that European Parliament has no institutional measures to alert the public (besides individual MEPs alerting the press, for example) raises concerns since, as recent research has shown, 'democratic 
controversy, transparency and critical debate' are mostly avoided. ${ }^{66}$ Parliamentary questions are the only form of public oversight. ${ }^{67}$ They are also published on the European Parliament's website, as well as in the EU's official journal. The caveat here is that the content of classified information will not be discussed. Hence, when oversight processes are open, crucial questions regarding classified information may be left unanswered by invoking executive secrecy.

Closed oversight is not unique to the European Parliament. Indeed, comparative examples from Member States show that they, too, despite long traditions of civil liberties, have adapted to, and adopted, oversight processes that seriously challenge public deliberation and fundamental rights in the face of security and the secrecy rules that are said to be necessary for such security policies. ${ }^{68}$ Moreover, the oversight of intelligence agencies has traditionally been more secluded from public view. What is different in the EU, however, is that oversight processes were negotiated behind closed doors by the executive and oversight institutions and established through interinstitutional agreements and internal rules of procedure. It is not possible to determine at the present stage what interests the European Parliament particularly defended or how the negotiations with the Council regarding access to classified information developed in more detail, since the majority of documents is also undisclosed or significantly redacted, even after more than a decade since these arrangements were made.

\section{Towards oversight and public deliberation}

The role and relevance of the European Parliament for advancing openness in the European Union and ensuring oversight of executive actors are its significant features as the only direct representative of the European citizens. The oversight role of the European Parliament has attracted significant interest, ${ }^{69}$ and there is a growing discussion on executive-legislative relations and the lack of information

66

67

69

Carrera, Hernanz and Parkin (n 29) 4.

European Parliament Rules of Procedure (n 33) rule 130.

See David Cole, Federico Fabbrini and Arianna Vedaschi (eds), Secrecy, National Security and the Vindication of Constitutional Law (Edward Elgar 2013).

Elisabeth Wisniewski, 'The Influence of the European Parliament on the European External Action Service' (2013) 18 Eur Foreign Aff Rev 81, 94. 
sharing. ${ }^{70}$ Moreover, the academic and policy debates have been expanding the way in which systems of EU official secrets function and the impacts of the latter for the oversight role of the European Parliament. ${ }^{71}$ Whereas this paper drew on these significant discussions, its contribution is not only to point to the challenges in parliamentary oversight due to executive secrecy and limits to access classified information, but also to develop in more detail a new aspect in the debate of European parliamentary oversight by showing how the European Parliament responded to these challenges and the resulting mode of oversight due to such efforts. In particular, neither the process nor the outcomes of parliamentary oversight are made public either to the other Members of the European Parliament, besides the committee members, or to the broader public. European parliamentary oversight predominantly takes place behind closed doors in the context of executive secrecy and under strict rules of official secrets. The European Parliament is using its new powers conferred by the Lisbon Treaty to assert its role in oversight, yet oversight behind closed doors does not enable citizens to gain a better understanding or have clarity on allocation of responsibilities on what the European Union does and whether these decisions are made at the national or European level.

Another key aspect of the European Parliament is that it has a unique role in fostering public deliberation in the EU. Hence, Parliamentary oversight is not merely about giving account, but also has a significant role to ensure space for citizens' participation. The key question, then, becomes to what extent the European Parliament is fostering processes of oversight, but also ensuring its deliberation function and bringing secrecy practices more into citizens' view. The necessity of openness for deliberation creates a higher threshold on the question of the extent to which secrecy should be limited because it requires that some information is available to the citizens. The European Parliament is yet to make serious efforts to develop its public deliberation function, and in doing so, to also bring attention to possible extensive secrecy practices. Significantly, closed oversight as it is conducted now could have the effect of making the European Parliament seem as part of an overall system of keeping EU official secrets that legitimises secrecy, but that creates a (further) separation and distance from the citizens whose rights and interests the European Parliament is constitutionally obliged to protect. the Euro Zone Summits (2013), Study requested by the European Parliament's Committee on Constitutional Affairs, 14 <http://www.europarl.europa.eu/RegData/etudes/etudes/ join/2013/474392/IPOL-AFCO_ET(2013)474392_EN.pdf > accessed 10 February 2016. 